\title{
Pendidikan Karakter: Konsep dan Implementasinya Dalam Pembelajaran di Sekolah/Madrasah
}

\author{
Muzhoffar Akhwan ${ }^{1}$
}

\begin{abstract}
Education is a medium to achieve values and meaning of life, rather than quantitative-artificial values. The true educatoin will help people to earn meaning for everything they learn all along education process. Meaning achievement is the main objective of learning process. There is no education when people do not achieve meaning through their education process. Many scholars found that, this circumstance may result from the lack of character building on education in the schools. However, character building education needs a good-spesific system that at least includes course details, tools teaching, methods, etc. Furthermore, this paper proposes learning methods that can be applied or further researched by teachers or scholars. Those methods are: 1) role model method; 2) habitual method; and 3) reward and punishment method.
\end{abstract}

Keywords: character building, education system, learning method.

${ }^{1}$ Penulis adalah dosen tetap Program Studi Pendidikan Agama Islam Fakultas Ilmu Agama Islam UII

\section{A. Pendahuluan}

Penguatan pendidikan moral (moraleducation) atau pendidikan karakter (character education) dalam konteks sekarang sangat relevan untuk mengatasi krisis moral yang sedang melanda di negara kita. Krisis tersebut antara lain meningkatnya pergaulan bebas, maraknya angka kekerasan anak-anak dan remaja, kejahatan terhadap teman, pencurian remaja, kebiasaan menyontek, penyalahgunaan obat-obatan, pornografi, dan perusakan milik orang lain sudah menjadi masalah sosial yang hingga saat ini belum dapat diatasi secara tuntas.

Krisis yang melanda pelajar mengindikasikan bahwa pendidikan agama dan moral yang didapat di bangku sekolah (kuliah) tidak berdampak terhadap perubahan perilaku manusia
Indonesia. Bahkan yang terlihat adalah begitu banyak perilaku manusia Indonesia yang tidak koheren dengan ucapannya. Kondisi demikian, diduga berawal dari apa yang dihasilkan oleh dunia pendidikan (Zubaidi, 2011: 2).

Demoralisasi terjadi karena proses pembelajaran cenderung mengajarkan pendidikan moral dan budi pekerti sebatas teks dan kurang mempersiapkan siswa untuk menyikapi dan menghadapi kehidupan dengan segala problematikanya. Dalam konteks pendidikan formal di sekolah/ madrasah, bisa jadi salah satu penyebabnya karena pendidikan di Indonesia lebih menitikberatkan pada pengembangan intelektual atau kognitif semata, sedangkan aspek soft skill atau non-akademik sebagai unsur utama pendidikan moral belum diperhatikan. 
Padahal, pencapaian hasil belajar siswa tidak dapat hanya dilihat dari ranah kognitif dan psikomotorik, sebagaimana selama ini terjadi dalam praktik pendidikan kita, tetapi harus juga dilihat dari hasil afektif. Ketiga ranah berhubungan secara resiprokal, meskipun kekuatan hubungannya bervariasi dari satu kasus ke kasus yang lain. Beberapa hasil penelitian menunjukkan bahwa efektivitas pencapaian hasil kognitif terjadi sejalan dengan efektivitas pencapaian ranah afektif (Hadjar, 2010: 215).

Dalam Renstra Kemendiknas 2010-2014 telah dicanangkan visi penerapan pendidikan karakter, maka diperlukan kerja keras semua pihak, terutama terhadap program-program yang memiliki kontribusi besar terhadap peradaban bangsa harus benar-benar dioptimalkan. Namun, penerapan pendidikan karakter di sekolah/ madrasah memerlukan pemahaman tentang konsep, teori, metodologi dan aplikasi yang relevan dengan pembentukan karakter (character building) dan pendidikan karakter (character education).

Berdasarkan persoalan di atas, maka tulisan ini akan membahas tentang pendidikan karakter yang mencakup konsep dan implementasinya dalam pembelajaran.

\section{B. Pembahasan}

\section{Konsep Pendidikan Karakter}

Pendidikan karakter telah menjadi perhatian berbagai negara dalam rangka mempersiapkan generasi yang berkualitas, bukan hanya untuk kepentingan individu warga negara, tetapi juga untuk warga masyarakat secara keseluruhan. Pendidikan karakter dapat diartikan sebagai to deliberate us of all dimensions of school life to foster optimal character development (usaha kita secara sengaja dari seluruh dimensi ke hidupan sekolah/madrasah untuk membantu pembentukan karakter secara optimal.

Menurut Lickona, karakter berkaitan dengan konsep moral (moral knowing), sikap moral (moral feeling), dan perilaku moral (moral behavior) (dalam Zubaidi, 2011: 29). Berdasarkan ketiga komponen ini dapat dinyatakan bahwa karakter yang baik didukung oleh pengetahuan tentang kebaikan, keinginan untuk berbuat baik, dan melakukan perbuatan kebaikan. Bagan di bawah ini merupakan bagan keterkaitan ketiga kerangka pikir ini.

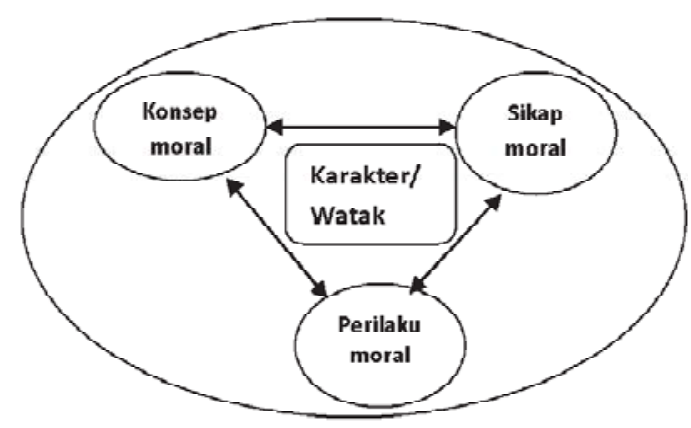

Gambar 1:

Keterkaitan antara komponen moral dalam rangka pembentukan Karakter yang baik menurut Lickona

Berdasarkan tujuan pendidikan nasional, maka pendidikan karakter adalah suatu program pendidikan (sekolah dan luar sekolah) yang mengorganisasikan dan menyederhanakan sumber-sumber moral dan disajikan dengan memerhatikan pertimbangan psikologis untuk pertimbangan pendidikan.

Tujuan pendidikan karakter adalah mengajarkan nilai-nilai tradisional tertentu, nilai-nilai yang diterima secara luas sebagai landasan perilaku yang baik dan bertanggungjawab. Nilai-nilai ini juga digambarkan sebagai perilaku moral (Zuchdi, 2009: 39). Pendidikan karakter selama ini baru dilaksanakan pada jenjang pendidikan pra sekolah/madrasah (taman kanak-kanak atau raudhatul athfâl). Sementara pada jenjang sekolah dasar dan 
seterusnya kurikulum di Indonesia masih belum optimal dalam menyentuh aspek karakter ini, meskipun sudah ada materi pelajaran Pancasila dan Kewarganegaraan. Padahal jika Indonesia ingin memperbaiki mutu sumber daya manusia dan segera bangkit dari ketinggalannya, maka Indonesia harus merombak sistem pendidikan yang ada, antara lain memperkuat pendidikan karakter.

Strategi pembelajaran yang berkenaan dengan moral knowing akan lebih banyak dipelajari melalui sumber belajar dan nara sumber. Pembelajaran moral loving akan terjadi pola saling membelajarkan secara seimbang di antara siswa. Sedangkan pembelajaran moral doing akan lebih banyak menggunakan pendekatan individual melalui pendampingan pemanfaatan potensi dan peluang yang sesuai dengan kondisi lingkungan siswa. Ketiga strategi pembelajaran tersebut sebaiknya dirancang secara sistematis agar para siswa dan guru dapat memanfaatkan segenap nilai-nilai dan moral yang sesuai dengan potensi dan peluang yang tersedia di lingkungannya.

Dengan demikian, hasil pembelajarannya ialah terbentuknya kebiasaan berpikir dalam arti peserta didik memiliki pengetahuan, kemauan dan keterampilan dalam berbuat kebaikan. Melalui pemahaman yang komprehensif ini diharapkan dapat menyiapkan pola-pola manajemen pembelajaran yang dapat menghasilkan anak didik yang memiliki karakter yang kuat dalam arti memiliki ketangguhan dalam keilmuan, keimanan, dan perilaku shalih, baik secara pribadi maupun sosial.

\section{Konsep Kurikulum}

Kurikulum merupakan rencana tertulis yang berisi tentang ide-ide dan gagasangagasan yang dirumuskan oleh pengembang kurikulum. Kurikulum dapat diartikan sebagai sebuah dokumen perencanaan yang berisi tujuan yang harus dicapai, isi materi dan pengalaman belajar yang harus dilakukan peserta didik, strategi dan cara yang dapat dikembangkan, evaluasi yang dirancang untuk mengumpulkan informasi tentang pencapaian tujuan, serta implementasi dari dokumen yang dirancang dalam kehidupan nyata. Komponenkomponen kurikulum saling berkaitan dan saling mempengaruhi, terdiri dari tujuan yang menjadi arah pendidikan, komponen pengalaman belajar, komponen strategi pencapaian tujuan, dan komponen evaluasi (Sanjaya, 2010: 16). Kurikulum berfungsi sebagai pedoman yang memberikan arah dan tujuan pendidikan.

Di era kurikulum 2004-2008 yang menggunakan kurikulum KBK dan KTSP, pembelajaran lebih mendapatkan penegasan pada kewenangan guru untuk menentukan indikator, pengalaman belajar, dan rangkaian belajar yang bisa mengantarkan tercapainya Kompetensi Dasar dan Standar Kompetensi yang sudah dibuat oleh pemerintah pusat. Bahkan pendidikan agama (PAI) dan pendidikan kewarganegaraan sudah mendapatkan pembobotan yang jelas, yakni PAI dengan akhlak mulia atau budi pekerti dan PPKN terkonsentrasi pada kepribadian. Kalau saja mata pelajaran ini bisa diturunkan dalam pembelajaran nyata di sekolah/madrasah, dengan fokus dan pendekatan yang jelas pada akhlak mulia, budi pekerti, dan kepribadian, seharusnya sudah bisa memberi harapan yang jauh lebih baik untuk memperbaiki akhlak siswa dibanding dengan harapan pada kurikulum sebelumnya. Namun untuk melakukan penguatan bagi perubahan perilaku peserta didik yang semakin berakhlak yang mengarah pada perolehan nilai-nilai hidup, bukan sematamata nilai angka yang hanya menggambarkan prestasi akademik, bukan belajar untuk 
berprestasi dalam kehidupan.

Desain kurikulum pendidikan karakter bukan sebagai teks bahan ajar yang diajarkan secara akademik, tetapi lebih merupakan proses pembiasaan perilaku bermoral. Nilai moral dapat diajarkan secara tersendiri maupun diintegrasikan dengan seluruh mata pelajaran dengan mengangkat moral pendidikan atau moral kehidupan, sehingga seluruh proses pendidikan merupakan proses moralisasi perilaku peserta didik. Bukan proses pemberian pengetahuan moral, tetapi suatu proses pengintegrasian moral pengetahuan.

Pendidikan karakter dipahami sebagai upaya menanamkan kecerdasan dalam berpikir, penghayatan dalam bentuk sikap, dan pengalaman dalam bentuk perilaku yang sesuai dengan nilai-nilai luhur yang menjadi jati dirinya (Zubaidi, 2011: 17). Penamaan pendidikan karakter tidak bisa hanya sekedar transfer ilmu pengetahuan atau melatih suatu keterampilan tertentu. Pendidikan karakter perlu proses, contoh teladan, pembiasaan atau pembudayaan dalam lingkungan peserta didik dalam lingkungan sekolah/madrasah, keluarga, lingkungan masyarakat, maupun lingkungan media massa.

Dari pengalaman ada dua pendekatan dalam pendidikan karakter, yaitu: (1) karakter yang diposisikan sebagai mata pelajaran tersendiri; dan (2) karakter yang built-in dalam setiap mata pelajaran. Sampai saat ini, pendekatan pertama ternyata lebih efektif dibandingkan pendekatan kedua. Salah satu alasannya ialah karena para guru mengajarkan masih seputar teori dan konsep, belum sampai ke ranah metodologi dan aplikasinya dalam kehidupan. Idealnya, dalam setiap proses pembelajaran mencakup aspek konsep (hakikat), teori (syariat), metode (tharikat) dan aplikasi (ma'rifat). Jika para guru sudah mengajarkan kurikulum secara komprehensif melalui konsep, teori, metodologi dan aplikasi setiap bidang studi, maka kebermaknaan yang diajarkannya akan lebih efektif dalam menunjang pendidikan karakter.

Nilai-nilai karakter antara lain: (1) Cinta kepada Allah I dan alam semesta beserta isinya; (2) tanggung jawab, disiplin dan mandiri; (3) jujur; (4) hormat dan santun; (5) kasih sayang, peduli, dan kerja sama; (6) percaya diri, kreatif, kerja keras dan pantang menyerah; (7) keadilan dan kepemimpinan, baik dan rendah hati, toleransi, cinta damai, dan persatuan. Implementasinya memerlukan kajian dan aplikasi nilai-nilai yang terkandung dalam karakter bangsa pada kegiatan pembelajaran di sekolah/madrasah. Integrasi nilai karakter bangsa pada kegiatan pembelajaran dapat dilakukan melalui tahap-tahap perencanaan, implementasi, dan evaluasi.

\section{Implementasi}

Proses pembelajaran pendidikan karakter secara terpadu bisa dibenarkan karena sejauh ini muncul keyakinan bahwa anak akan tumbuh dengan baik jika dilibatkan secara alamiah dalam proses belajar. Istilah terpadu dalam pembelajaran berarti pembelajaran menekankan pengalaman belajar dalam konteks yang bermakna. Pengajaran terpadu dapat didefinisikan sebagai suatu konsep pendekatan belajar yang melibatkan beberapa bidang studi untuk memberikan pengalaman yang bermakna bagi peserta didik. Dikatakan bermakna karena dalam pembelajaran terpadu, peserta didik akan memahami konsep yang dipelajari melalui pengalaman langsung dan menghubungkannya dengan konsep lain yang sudah dipahaminya melalui kesempatan mempelajari apa yang berhubungan dengan tema atau peristiwa autentik (alami). 
Dengan demikian, ciri pendidikan terpadu adalah: (1) berpusat pada peserta didik; (2) memberikan pengalaman langsung kepada peserta didik; (3) pemisahan bidang studi tidak begitu jelas; (4) menyajikan konsep dari berbagai bidang studi dalam suatu proses pembelajaran; (5) bersifat luwes, dan (6) hasil pembelajaran dapat berkembang sesuai dengan minat dan kebutuhan peserta didik (Zubaidi, 2011: 268).

Integrasi pembelajaran dapat dilakukan dalam substansi materi, pendekatan, metode, dan model evaluasi yang dikembangkan. Tidak semua substansi materi pelajaran cocok untuk semua karakter yang akan dikembangkan, perlu dilakukan seleksi materi dan sinkronisasi dengan karakter yang akan dikembangkan. Pada prinsipnya semua mata pelajaran dapat digunakan sebagai alat untuk mengembangkan semua karakter peserta didik, namun agar tidak terjadi tumpang-tindih dan terabaikannya salah satu karakter yang akan dikembangkan, perlu dilakukan pemetaan berdasarkan kedekatan materi dengan karakter yang akan dikembangkan.

Dari segi pendekatan dan metode, pemetaan yang bisa dilakukan meliputi inkulkasi (inculcation), keteladanan (modeling, qudwah), fasilitasi (facilitation), dan pengembangan keterampilan (skill building) (Zuchdi, 2009: 46-50). Inkulkasi (penanaman) nilai memiliki ciri-ciri: (1) mengomunikasikan kepercayaan disertai alasan yang mendasarinya; (2) memperlakukan orang lain secara adil; (3) menghargai pandangan orang lain; (4) mengemukakan keragu-raguan disertai alasan, dan dengan rasa hormat; (5) tidak sepenuhnya mengontrol lingkungan untuk meningkatkan kemungkinan penyampaian nilai-nilai yang dikehendaki; (6) menciptakan pengalaman sosial dan emosional mengenai nilai-nilai yang dikehendaki secara tidak ekstrem; (7) membuat aturan, memberikan penghargaan, dan memberikan konsekuensi disertai alasan; (8) tetap membuka komunikasi dengan pihak yang tidak setuju, dan (9) memberikan kebebasan bagi adanya perilaku yang berbeda-beda, apabila sampai pada tingkat yang tidak dapat diterima, diarahkan untuk memberikan kemungkinan berubah. Pendidikan karakter seharusnya tidak menggunakan metode indoktrinasi yang memiliki ciri-ciri yang bertolak belakang dengan inkulkasi.

Dalam pendidikan karakter, pemodelan atau pemberian teladan merupakan strategi yang biasa digunakan. Untuk dapat menggunakan strategi ini ada dua syarat yang harus dipenuhi. Pertama, guru harus berperan sebagai model yang baik bagi peserta didik dan anaknya. Kedua, peserta didik harus meneladani orang terkenal yang berakhlak mulia, misalnya Nabi Muhammad e. Cara guru menyelesaikan masalah dengan adil, menghargai pendapat anak dan mengritik orang lain dengan santun, merupakan perilaku yang secara alami dijadikan model bagi anak.

Inkulkasi dan metode keteladanan (alqudwah) kepada peserta didik merupakan cara terbaik untuk mengatasi berbagai masalah; orang akan melakukan proses identifikasi, meniru, dan memeragakannya. Dengan metode pembiasaan, seseorang akan memiliki komitmen yang hebat. Pembiasaan dalam penanaman moral merupakan tahapan penting yang seharusnya menyertai perkembangan setiap mata pelajaran. Mengajari moral tanpa pembiasaan melakukannya, hanyalah menabur benih ke tengah lautan, karena moral bukan sekedar pengetahuan, tetapi pembiasaan bermoral. Fasilitasi melatih peserta didik mengatasi masalah-masalah tersebut. Kegiatan-kegiatan yang dilakukan peserta didik dalam melaksana- 
kan metode fasilitasi membawa dampak positif pada perkembangan kepribadian peserta didik.

Pembelajaran moral bagi peserta didik akan lebih efektif apabila disajikan dalam bentuk gambar, seperti film, sehingga peserta didik bukan saja menangkap maknanya dari pesan verbal mono-pesan, melainkan bisa menangkap pesan yang multi-pesan dari gambar, keterkaitan antargambar dan peristiwa dalam alur cerita yang disajikan (Mursidin, 2011: 8182). Contoh: penyampaian pesan bahwa narkoba itu harus dihindari, maka tayangan tentang derita orang-orang yang dipenjara karena korban narkoba jauh lebih bermakna daripada disampaikan secara lisan, melalui metode ceramah. Namun demikian, bila ingin lebih mendalam tingkat penerimaan mereka, bisa dilanjutkan dengan metode renungan (almuhasabah) setelah terkondisikan dengan baik melalui cerita dalam film yang baru saja ditayangkan.

Kecerdasan, keterampilan, dan ketangkasan seseorang berbeda-beda, sebagaimana perbedaan dalam temperamen dan wataknya. Ada yang memiliki temperamen tenang, mudah gugup atau grogi. Ada yang mudah paham dengan isyarat saja apabila salah dan ada yang tidak bisa berubah, kecuali setelah melihat mata membelalak, bahkan dengan bentakan, ancam an, dan hukuman secara fisik. Sekalipun hukuman pukulan merupakan salah satu metode dalam pendidikan, semestinya guru tidak menggunakannya sebelum mencoba dulu dengan cara lain. Metode hukuman digunakan untuk menggugah serta mendidik perasaan rabbaniyah, yaitu perasaan khauf (takut) dan khusyu' ketika mengingat Allah dan membaca al-Qur' an (al-Nahlawi, 2007: 232-233; Amin, 1929: 3).

Beberapa keterampilan diperlukan agar seseorang dapat mengamalkan nilai yang dianut sehingga berperilaku konstruktif dan bermoral dalam masyarakat. Keterampilan tersebut antara lain:

a. Keterampilan berpikir kritis, dengan ciriciri sebagai berikut: (1) mencari kejelasan pernyataan atau pertanyaan; (2) mencari alasan; (3) mencoba memperoleh informasi yang benar; (4) menggunakan sumber yang dapat dipercaya; (5) mempertimbangkan keseluruhan situasi; (6) mencari alternatif; (7) bersikap terbuka.

b. Keterampilan mengatasi masalah. Masih banyak orang mengatasi konflik dengan kekuatan fisik, padahal cara demikian itu biasa digunakan oleh binatang. Manusia yang menggunakan nilai religius dan prinsip moral dalam penyelesaian masalah kehidupan, perlu diajarkan cara mengatasinya yang konstruktif.

Perilaku moral (moral action) dapat dievaluasi secara akurat dengan melakukan observasi dalam jangka waktu yang relatif lama dan secara terus menerus. Pengamat atau pengobservasi harus orang yang sudah mengenal orang-orang yang diobservasi agar penafsirannya terhadap perilaku yang muncul tidak salah.

\section{Kesimpulan}

Berdasarkan pembahasan di atas, maka dapat disimpulkan beberapa poin penting sebagai berikut:

1. Pendidikan yang hakiki merupakan ikhtiar untuk memperoleh nilai hidup, bukan nilai angka sebagaimana lazimnya saat ini. Menghasilkan makna dari setiap pengetahuan yang dipelajarinya. Pemerolehan makna menjadi ukuran dari setiap proses pembelajaran. Tak ada proses belajar, bila belum menghasilkan rekonstruksi makna baru yang dapat memberikan pencerahan bagi si pembelajar. 
2. Dunia pendidikan kita lebih sering menggunakan tes yang mengukur ranah pengetahuan ketimbang untuk mengukur ranah afektif. Soal-soal pada saat ulangan atau ujian nasional pun lebih banyak menuntut kemampuan kognitif daripada mengukur ranah afektif, akibatnya produk pendidikannya, output atau outcome, kurang memiliki moralitas yang baik. Tidak malu melakukan korupsi, tidak takut berbuat dosa dan kesalahan, serta tidak resah bila berbuat kezaliman.

3. Pendidikan karakter memerlukan metode khusus yang tepat agar tujuan pendidikan dapat tercapai. Di antara metode pembelajaran yang sesuai adalah metode keteladanan (al-qudwah), metode pembiasaan, dan metode pujian dan hukuman.

\section{Daftar Pustaka}

Al-Abd, Abdullatîf Muhammad. Tt. al-Akhlâq fi Al-Islâm. Cairo: Universitas Cairo.

Al-Nahlawy, Abd al-Rahman. 2007. Ushîl alTarbiyah al-Islâmiyah wa Asâlibuha fi al-Bait wa al-Madrasah wa al-Mujtama', edisi ke-25. Damaskus: Dar al-Fikr.
Amin, Ahmad. 1929. Kitâb al-Akhlâq. Cairo: Dar al-Kutub al-Mishriyah.

Daradjat, Zakiyah, et. al. 2011. Ilmu Pendidikan Islam, cet. 9. Jakarta: Bumi Aksara.

Hadjar. Tt. Evaluasi Hasil Belajar Afektif Pendidikan Agama: Konsep dan Pengukurannya. Muntholi'ah (ed.), Guru Besar Bicara Mengembangkan Keilmuan Pendidikan Islam. Semarang: Fakultas Tarbiyah.

Mursidin. 2011. Moral Sumber Pendidikan, Sebuah Formula Pendidikan Budi Pekerti di Sekolah/ Madrasah. Bogor: Ghalia Indonesia.

Sanjaya. 2010. Kurikulum dan Pembelajaran. Jakarta: Kencana Prenda Media Group.

Zubaidi. 2011. Desain Pendidikan Karakter. Jakarta: Prenada Media Group.

Zuchdi, Darmiyati. 2009. Humanisasi Pendidikan. Jakarta: Bumi Aksara. 